\title{
Педіатрія
}

УдК 616. 33 /.34- 053. 5- 071.- 038

®С. Л. Няньковський, О. М. Сенкевич

Львівський національний медичний університет імені Данила Галицького

\section{ДИНАМІКА ПОШИРЕНОСТІ СКАРГ ТА ФАКТОРІВ РИЗИКУ, ХАРАКТЕРНИХ ДЛЯ ПОРУШЕННЯ ТРАВНОЇ СИСТЕМИ В ДІТЕЙ МОЛОДШОГО ШКІЛЬНОГО ВІКУ}

ДИНАМІКА ПОШИРЕНОСТІ СКАРГ ТА ФАКТОРІВ РИЗИКУ, ХАРАКТЕРНИХ ДЛЯ ПОРУШЕННЯ ТРАВНОЇ СИСТЕМИ В ДІТЕЙ МОЛОДШОГО ШКІЛЬНОГО ВІКУ. У статті подано результати аналізу поширеності скарг, симптомів та факторів ризику дітей молодшого шкільного віку, пов'язаних з розвитком гастродуоденальної патології. Проведено аналіз факторів ризику щодо найбільш розповсюджених захворювань шлунково-кишкового тракту. Сформовано концепцію необхідності виділення дітей молодшого шкільного віку з гастродуоденальною патологією в окрему групу з метою подальшого обстеження, діагностики, профілактики та лікування. Протягом останніх 10 років спостерігаються зменшення частки здорових школярів, посилення скарг, характерних для функціональних розладів травної системи.

ДИНАМИКА РАСПРОСТРАНЕННОСТИ ЖАЛОБ И ФАКТОРОВ РИСКА, ХАРАКТЕРНЫХ ДЛЯ НАРУШЕНИЯ ПИЩЕВАРИТЕЛЬНОЙ СИСТЕМЫ У ДЕТЕЙ МЛАДШЕГО ШКОЛЬНОГО ВОЗРАСТА. В статье поданЫ резуЛЬтатЫ аналИза распространенности жалоб, симптомов и факторов риска детей младшего школьного возраста, связанных с развитием гастродуоденальной патологии. Проведен анализ факторов риска в отношении наиболее распространенных заболеваний желудочно-кишечного тракта. Сформирована концепция необходимости выделения детей младшего школьного возраста с гастродуоденальной патологией в отдельную группу для дальнейшего обследования, диагностики, профилактики и лечения. В течение последних 10 лет наблюдаются уменьшение доли здоровых школьников, усиление жалоб, характерных для функциональных расстройств пищеварительной системы.

COMPLAINTS PREVALENCE AND RISK FACTORS SPECIFIC TO VIOLATIONS OF THE DIGESTIVE SYSTEM OF CHILDREN OF PRIMARY SCHOOL AGE. In the article we show the results of analysis of complaints prevalence, symptoms and risk factors prevalence in children of primary school age, related to development of gastro-duodenal pathology. Risk factors discussed in relation to most of ten widespread diseases of gastrointestinal tract. We foremed the conception of necessity of selection of primary school aged children with gastro-duodenal pathology in a separate group with the aim of further supervision, diagnostics, prophylaxis and treatment. During the last 10 years there is reduction of part of healthy school children, strengthening of complaints characteristic for functional disorders of digestive system.

Ключові слова: діти молодшого шкільного віку, патологія, шлунково-кишковий тракт.

Ключевые слова: дети младшего школьного возраста, патология, желудочно-кишечный тракт.

Key words: children in primary school age, pathology, gastrointestinal tract.

ВСТУП. Медичною наукою стверджено, що близько $75 \%$ хвороб у дорослих - родом 3 дитинства та юності. Хронічні захворювання у молодих людей найчастіше формуються на ранніх етапах розвитку - в дошкільному віці чи в перші роки навчання в школі, якщо схильність до хронічних захворювань, їх ранні ознаки були залишені без уваги [2, 4].

Негативними сучасними тенденціями щодо стану здоров'я дітей $є$ такі, як прогресуюче поширення хронічної соматичної патології та іï «помолодшання»; зростання розповсюдженості нервово-психічних захворювань; підвищення частоти уроджених вад розвитку; відродження старих інфекцій (сифіліс, туберкульоз) та поширення нових (ВІЛ); кількісне зростання та розповсюдженість екологічно детермінованих синдромів і захворювань; збільшення кількості наркотично-, алкогользалежних, курців серед дітей шкільного віку; загрозливе поширення явища соціального сирітства, соціальної дезадаптації, дитячої інвалідності [2].

У Державній доповіді про становище дітей в Україні повідомляється, що впродовж останніх років зберігається стала тенденція до погіршення стану здоров'я дітей $[1,5]$.
Аналіз рівня поширеності гастродуоденальної патології свідчить, що в останні роки є типовою трансформація функціональних порушень у хронічний патологічний процес, який характеризується тривалим та рецидивним перебігом, відносною резистентністю до застосованої терапії [3]. Така ситуація вимагає розробки та впровадження нових підходів до пошуку дітей з груп ризику та їх диспансерного спостереження. За інформацією Центру медичної статистики МОЗ України, щороку в нашій країні вперше реєструється майже 50000 дітей з хронічним гастродуоденітом, який у структурі захворюваності органів травлення складає 58-74 \%. В останнє десятиріччя спостерігаються «помолодшання» захворюваності органів травлення та збільшення частоти гастритів i гастродуоденітів [2].

Зважаючи на вищенаведені дані, актуальним $€$ вивчення сучасних тенденцій формування патології травної системи у дітей молодшого шкільного віку для визначення пріоритетів при проведенні профілактичної та оздоровчої роботи.

МАТЕРІАЛИ ТА МЕТОДИ. Проведено порівняльний аналіз результатів анкетного опитування батьків та дітей віком 6-11 років у школах міста Львова у 
$2002(n=5000)$ та анкетного опитування 3 подальшим поглибленим оглядом у 2012-2013 роках (п=291). Робота проводилась за сприяння Львівської міської ради, Управління освіти Львівської області та благодійного фонду «Крила надії».

Статистичний аналіз отриманих даних був проведений за допомогою програми STATISTICA. Дані, що підлягають закону нормального розподілення, представлені у вигляді середніх значень і стандартних відхилень. Дані, що не підлягають закону нормального розподілення, представлені у вигляді медіани.

Анкета складається з блоків запитань, пов'язаних з медико-соціальними особливостями школярів, поширеністю скарг, пов'язаних з розвитком патології шлунково-кишкового тракту (ШКТ), факторами ризику, що можуть спричиняти захворювання травної системи, віковими особливостями розвитку патології ШКТ у школярів.

РЕЗУЛЬТАТИ ДОСЛІДЖЕННЯ ТАЇХ ОБГОВОРЕННЯ. У загальній групі в 2012 році під спостереженням перебувала 291 дитина віком від 6 до 11 років. 3 них, за даними анкетного опитування, 3 \% батьків вважали своїх дітей здоровими, 97 \% батьків - хворими. Середній вік дітей склав 8 років, 3 них хлопчиків - $51 \%$, дівчаток - $49 \%$. Середній показник зросту в загальній групі - 130,5 см, маси - 28,2 кг.

За результатами анкетування, 26 дітей було зараховано до групи здорових. Критерієм зарахування до групи здорових була відсутність таких скарг, як дискомфорт і біль у животі, нудота, блювання, печія та відрижка. Решту дітей віднесено до групи, яка потребує консультації, спостереження чи обстеження.

Основні скарги, що виникали у дітей і, ймовірно, пов'язані із захворюваннями шлунково-кишкового тракту, наведено на рисунку 1.

Відмічено 6 основних скарг у дітей у 2012 році, частота яких збільшилась порівняно з 2002 роком. Як засвідчують наші результати, найбільш поширеною скаргою у 2012 році були дискомфорт та біль у животі, які зустрічалися з поширеністю 82 \% і збільшилися, порівняно з 2002 роком, на $8 \%$. Також зросла частка дітей зі скаргами на відрижку (20\% у 2002 та $71 \%$ у 2012 роках), печію (7 і $12 \%$ ), нудоту та періодичне блювання (29 і 56 \%), закрепи (32 і 36 \%) та швидку втомлюваність (46 і 78 \% відповідно). Ці дані підтверджують тенденцію до зростання кількості патології травної системи протягом останніх 10 років. Водночас зареєстровано деяке зменшення пошире- ності скарг на запаморочення у дітей, що є одним із симптомів астенічного синдрому.

Зростання поширеності симптомів та скарг, пов'язаних з гастродуоденальною патологією у дітей, вказує на важливість факторів, які тією чи іншою мірою сприяють або спричиняють розвиток захворювань шлунково-кишкового тракту в дітей.

В нашій роботі можливі фактори ризику було поділено на 3 основні групи. Ці фактори з великою ймовірністю мають найбільший вплив на стан шлунковокишкового тракту в дітей молодшого шкільного віку. Сучасні науковці вважають, що приблизно на 20 \% стан здоров'я залежить від впливу на нього зовнішнього довкілля, 20 \% припадає на генетичні фактори та спадковість, $50 \%$ - на спосіб життя, а решта $10 \%$ - на систему охорони здоров'я та професійні шкідливості.

Існують докази того, що генетичні фактори сприяють розвитку захворювань ШКТ. Важливо відмітити, що це гетерогенні захворювання, на формування яких впливає сукупність різних чинників. Під час анкетування визначено, що достовірним є збільшення частки дітей зі скаргами, в сім'ях яких родичі мають захворювання ШКТ та цукровий діабет. Водночас ми не виявили впливу надмірної маси тіла батьків на частоту гастродуоденальних скарг у дітей (рис. 2).

За результатами анкетного опитування, антропометричні виміри та фізичний розвиток здорових дітей та дітей зі скаргами у 2012 році не відрізнялись. Відомим $€$ той факт, що вживання коров'ячого молока на першому році життя підвищує ризик розвитку патології ШКТ через високу "алергізацію», що підтвердилось у нашому дослідженні. Заслуговують уваги дані щодо вживання молочних сумішей 3 перших днів життя. 3'являється все більше даних, що штучне вигодовування може як сприяти захворюванням в ранньому віці (харчова алергія, целіакія), так і проявляти себе в більш віддалені терміни. Ми отримали достовірні дані, що гестози, особливо у першому триместрі вагітності, а також перебування вагітної жінки у стаціонарі підвищують ризик виникнення гастродуоденальної патології у дітей молодшого шкільного віку. Не можна недооцінювати вплив на дітей факторів екологічного неблагополуччя, особливо у промислових районах і великих містах. Шкідливі звички батьків (а часом і дітей віком до 11 років), соціальні умови життя, як окремо, так і в сукупності, негативно впливають на стан шлунково-кишкового тракту в дітей (рис. 3).

\begin{tabular}{|c|c|c|c|c|c|c|c|c|c|c|}
\hline $40 \%$ & & & & & & & & & & \\
\hline \multicolumn{11}{|l|}{$20 \%$} \\
\hline nio & $\begin{array}{l}\text { дискомфорт в } \\
\text { животі }\end{array}$ & нудота & печія & блювання & відрижка & $\begin{array}{c}\text { запаморо- } \\
\text { чення }\end{array}$ & $\begin{array}{c}\text { швидка } \\
\text { втомлюваність }\end{array}$ & закрепи & діарея & біль голови \\
\hline 2002 & $74 \%$ & $47 \%$ & $7 \%$ & $29 \%$ & $50 \%$ & $15 \%$ & $46 \%$ & $32 \%$ & $48 \%$ & $62 \%$ \\
\hline 2012 & $82 \%$ & $41 \%$ & $12 \%$ & $56 \%$ & $71 \%$ & $11 \%$ & $78 \%$ & $36 \%$ & $47 \%$ & $58 \%$ \\
\hline
\end{tabular}

Рис. 1. Поширеність та динаміка скарг у дітей молодшого шкільного віку, пов'язані 3 патологією шлунково-кишкового тракту, з 2002 до 2012 року. 


\section{Педіатрія}

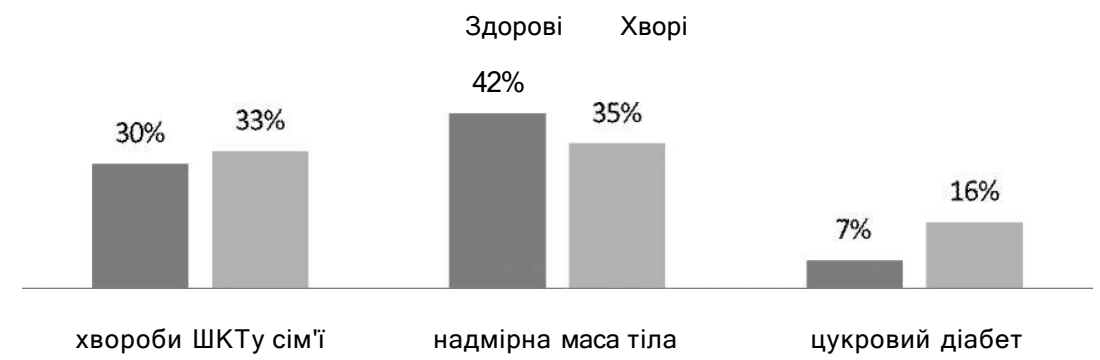

Рис. 2. Генетичні фактори ризику, що впливають на розвиток гастродуоденальної патології дітей молодшого шкільного віку, в 2012-2013 роках.

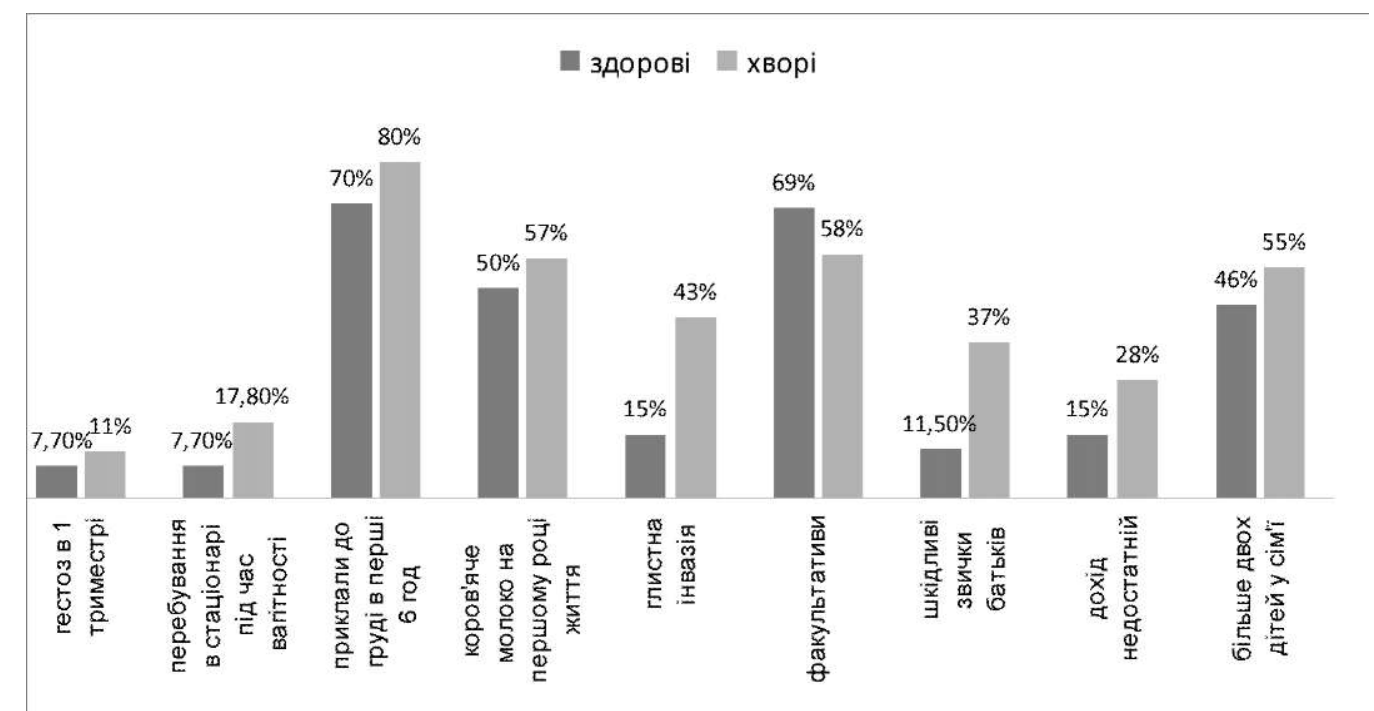

Рис. 3. Фактори ризику залежно від екологічних та соціальних умов життя, що мають вплив на розвиток гастродуоденальної патології у дітей молодшого шкільного віку, в 2012-2013 роках.

Наслідки гастроентерологічних захворювань не завжди можна передбачити. Тезу, що початки захворювань органів ШКТ у дорослих знаходяться у дитинстві, можна розглядати як аксіому [6]. В такому випадку їі ми можемо екстраполювати і на дитячий вік. Це означає, що у більшості підлітків маніфестація захворювань ШКТ проходить у дошкільному та молодшому шкільному віці [6]. На даний час для педіатрів актуальним $є$ пошук скринінгових методів для виділення пацієнтів групи ризику. Та поки що тенденція виділяти дітей молодшого шкільного віку в окрему групу при призначенні лікування та проведенні профілактичних заходів не набула широкої популярності серед педіатрів. Тому вивчення поширеності та динаміки скарг, симптомів та факторів ризику, пов'язаних із захворюваннями шлунково-кишкового тракту, при опрацюванні комплексної системи профілактики захворювань органів травлення у дітей молодшого шкільного віку дозволить нам виробити такий алгоритм, що враховував би і найчастіші скарги, і найімовірніші фактори ризику, характерні для даного віку дітей. Це, у свою чергу, могло б полегшити та пришвидшити роботу педіатрів [7]

На сьогодні доцільно користуватись алгоритмом, який нам запропонувала А. А. Камалова
(2011 рік). Проте він також потребує певного вдосконалення.

ВИСНОВКИ. На сьогодні існує стійка тенденція до погіршення стану здоров'я дітей молодшого шкільного віку. Значна частина патології припадає на функціональні розлади та захворювання травної системи, що вимагає розробки нових підходів до раннього виявлення дітей з факторами ризику та їх подальшого спостереження. Серед основних скарг, що супроводжують формування патології шлунково-кишкового тракту в дітей, виділено такі, як дискомфорт та біль у животі, нудота, відрижка, астенічний синдром. До головних факторів ризику слід віднести захворювання шлунково-кишкового тракту в сім'ї, цукровий діабет, характер харчування на першому році життя, режим харчування, соціально-економічне благополуччя сім'ї, екологічні чинники.

ПЕРСПЕКТИВИ ПОДАЛЬШИХ ДОСЛІДЖЕНЬ. ПОдальші дослідження поширеності скарг, факторів ризику, а також наступне вивчення клінічних особливостей перебігу гастродуоденальної патології та їх динаміки у дітей молодшого шкільного віку дозволять розробити прогностичні критерії для ранньої діагностики захворювань шлунково-кишкового тракту і змінити підхід до профілактики та лікування. 


\section{Педіатрія}
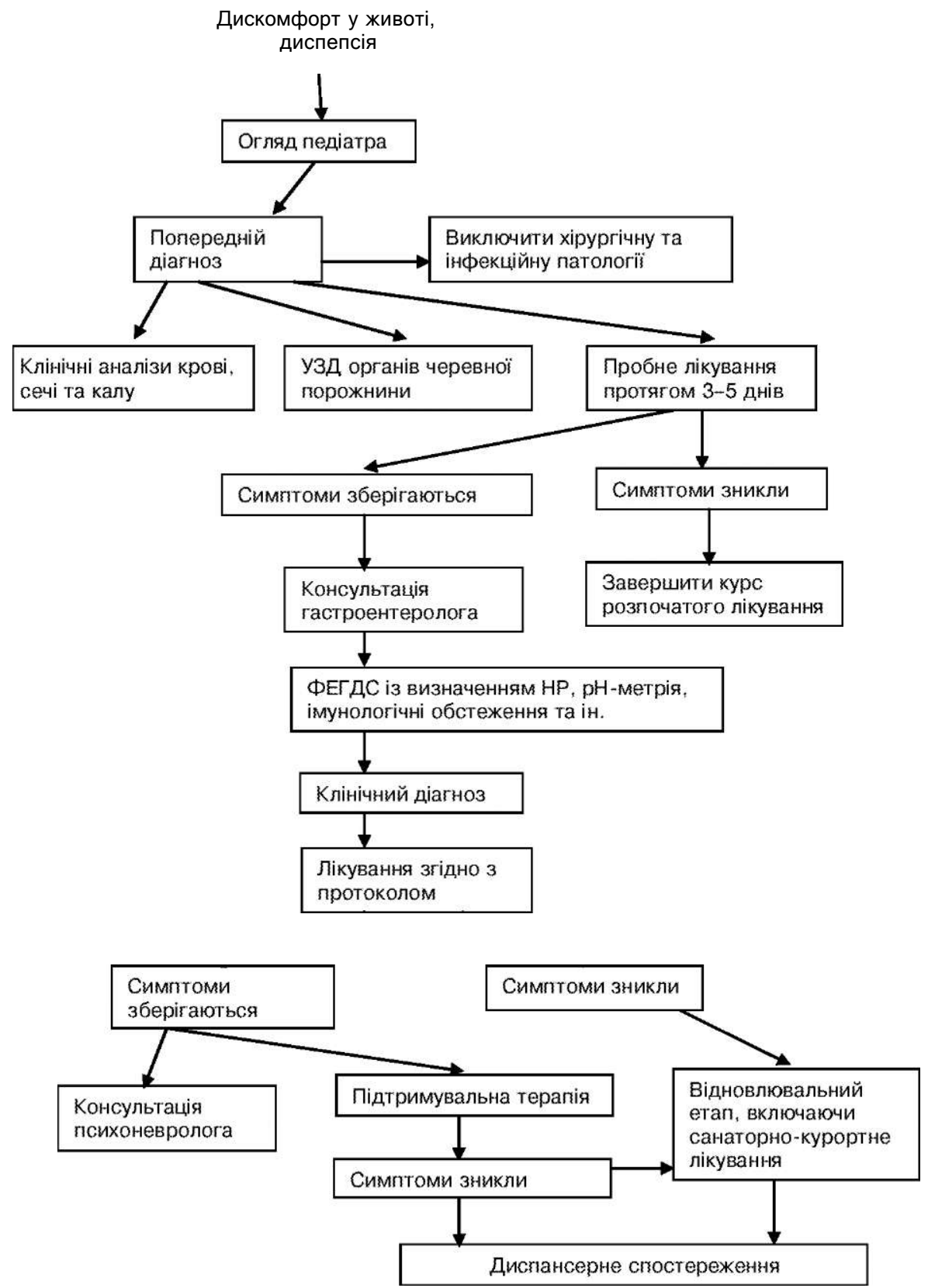

\section{СПИСОК ЛІТЕРАТУРИ}

1. Державна доповідь про становище дітей в Україні (за підсумками 2010 року) / [Т. Ф. Алєксєєнко, С. Ю. Аксьонова, О. В. Вакуленко та ін.]. - К., 2011. $195 \mathrm{C}$.

2. Охорона здоров'я України: стан, проблеми, перспективи / [В. М. Князевич, В. В. Лазоришинець, І. В. Яковенко та ін.]. - К., 2009. - 438 с.

3. Рішення звітної наради 3 питань охорони материнства та дитинства від 21.02.2012 р. Розділ - Педіатрія.

4. Выхристюк О. Ф. Проблемы хронической патологии в детском возрасте и демографическая ситуация / О. Ф. Выхристюк, Г. А. Самсыгина // Мед. науч. практ. журн. - 1998. - № 4. - С. 8-14.
5. Аналіз та тенденції захворюваності дитячого населення України / Р. О. Моісеєнко, Я.І.Соколенко, Т. К. Кульчицька, Т. М. Бухановська // Совр. педиатрия. - 2010. - № 3 (31). - С. 13-17.

6. Запруднова А. М. Современные особенности подростковой гастроэнтерологии / А. М. Запруднов, К. И. Григорьев // Педиатрия. - 2011. - Т. 90, № 2. C. 7-13.

7. Функциональные состояния желудка и протеолитическая активность копрофильтратов у детей с хронической гастродуоденальной патологией / А. А. Камалова, Э. И. Удачина, О. Д. Зинкевич, Н. А. Сафина // Педиатрия. - 2011. - Т. 90, № 2. - С. 14-18.

Отримано 10.02 .15 